\title{
Comparison between dexmedetomidine and propofol as sedatives for critically ill patients in intensive care units
}

\author{
Sabah N. AL-Saad* \\ Haitham A. Sahib AI-Jaafari **
}

\author{
FICMS, CABA\&IC \\ FICMS, CABA\&IC
}

\section{Abstract:}

Background: Regarding using of sedation in the intensive care unit (ICU) should allow the patient to be more comfortable, calm, cooperative, and at the same time easily arousable without delay niether weaning nor prolonged mechanical ventilation.

Fac Med Baghdad 2018; Vol.60, No.1 Objective: The aim of my study is to compare the effect of dexmeditomidine Versus propofol for sedation and hemodynamic stability in critically ill patient.

Received: Feb., 2018

Accepted: Mar., 2018

Patient and method: A randomized study of 44 patients admitted to ICU; 22 of them received dexmedetomidine and the other 22 patients received propofol for sedation. The level of consciousness, blood pressure, heart rate, respiratory rate and requirement for adjuvants to reach the target level of sedation were monitored for the first 12 hours.

Result: By applying Null hypothesis it was found that dexmedetomidine was significantly effective when compared with propofol for sedation with p-value less than 0.001 , while it was not significantly effective when compared with propofol plus adjuvant with p-value> 0.05 .

Conclusion: Dexmedetomidine is effective as a sole sedative agent with haemodynamic stability without the need to add any adjuvant to it, while propofol cause hypotension and bradycardia if used alone to reach our target level of sedation, but can be used with adjuvant to reach our target of sedation and haemodynamic stability.

Keywords: Dexmedetomidine, Propofol, Sedation, ICU.

\section{Introduction:}

Sedation is a state of reduced consciousness in which verbal contact with patients may be maintained.(1)the role of using sedation in the ICU allows for a comfortable quite cooperative patient, decreases the levels of anxiety and stress, reduces insomnia and the risk of awareness and the agitated movement during any stressful interventions, and normalizes metabolism and haemodynamics. (2) Although there are many scales for sedation assessment, Riker Sedation-Agitation Scale (SAS) was selected because of it is more practical and applicable.(3) regarding feature of ideal sedative should provide a rapid onset of effect and a rapid recovery and should have a low propensity to accumulate, leaving no withdrawal effects meaning of any unwanted side effects. It should be easily treatable and should not compromise haemodynamic stability. (4) Presynaptic $\alpha 2$ receptors interfere with release of norepinephrine and adenosine triphosphate through a negative feedback mechanism. (5) Receptors for $\alpha 2$ are found in the peripheral and central nervous systems, platelets, and a variety of organs. Physiologic responses mediated by $\alpha 2$ adrenoreceptors vary with location. (6) Dexmedetomidine It is a short-acting a2-

*Dept. of Surgery- Anastasia, College of medicine, University of Baghdad.

**Al Karkh General Hospital, Alkarkh health Directorate Baghdad.

Email:haithemabdulsattar@yahoo.com agonist with anxiolytic, anesthetic, hypnotic, and analgesic properties.(7) dexmedetomidine $\mathrm{HCl}$, an imidazole compound, is 8 times more selective for $\alpha 2$ than clonidine, (8) so it shows a high ratio of specificity for $\alpha 2$ receptor ( $\alpha 2 \backslash \alpha 1$ 1600:1), compared with clonidine ( $\alpha 2 \backslash \alpha 1 \quad 200: 1)$ making it complete $\alpha 2$ agonist.(9) Sedation by dexmedetomidine has been termed cooperative sedation, as it allows the patient to interact with healthcare professionals.(10)Loading dose $1 \mu \mathrm{g} \mathrm{kg}$ for $10-20$ minute, continuous dose $0.2-$ $0.7 \mu \mathrm{g} \backslash \mathrm{kg} \backslash \mathrm{hr} .(11)$ Side effect (Hypotension, Hypertension, Nausea, Bradycardia, Atrial fibrillation and Hypoxia).(12) Propofol it is a phenol derivative which has achieved great popularity because of its favorable recovering characteristics and its anti-emetic effect.(13) Chemical structure : 2,6Diisopropylphenol.(14)Intralipid contain $10 \%$ soybean oil, $2.25 \%$ glycerol and $1.2 \%$ egg lecithine.(15)The mechanism by which Propofol induces state of GA or sedation may involve facilitation of inhibitory neurotransmission mediated by GABA receptor.(16)Sedative dose infusion 25-75 $\mu \mathrm{g} \backslash \mathrm{kg} \backslash \min .(17)$

\section{Patients and methods:}

A comparative clinical trial conducted at Baghdad teaching hospital \& surgical specialty hospital, medical city, Iraq, during the period between May 2011 to March 2013.(44) patients were selected to participate in the study, their ages ranged from $16-65$ years,medical and surgical patients,heamodynamically 
stable,ventilated via orotracheal tube, conscious and oriented patients, the patients were divided into 2 groups; group A were ICU patients who received dexmedetomidine \& group B were ICU patients for whom propofol was prescribed for sedation. Patients with head injury, Glasco Coma Scale (GCS) $<8$, tracheostomised patients, ASA III, patients require muscle relaxant for mechanical ventilation,patients with liver \& renal diseases,patients with acute neurological disorders,loss of hearing or vision or conditions interfering with assessment were excluded from the study. Twenty two patients were included in group A \& another Twenty two patients were included in group B. All patients were admitted to ICU for a wide range of causes, (surgical and medical).They were studied and categorized according to their response to sedative agents, where sedation level was determined according to Riker sedation- agitation scale (3). All patients in both groups were monitored regarding their blood pressure, pulse rate and respiratory rate. For group $\mathrm{A}$, if a patient met the selection criteria, then he was thoroughly examined and worked up. Then after a bolus dose of dexmedetomidine $(1 \mu \mathrm{g} / \mathrm{kg})$ was given and the patient was followed up after $1 \mathrm{hr}$. and his/her vital signs were measured and classified on the base of Riker's scale, then for the next 12 hours the patients was maintained with dexmedetomidine using infusion pump in a dose range between $0.2-0.7 \mu \mathrm{g} / \mathrm{kg} / \mathrm{hr}$. During this period the patient was followed up to recognize the maintenance dose that keeps the patient at level (3) on Riker's scale, with continuous monitoring of the effect of drug on vital signs. For group $\mathrm{B}$, propofol was used in a sedative dose $(25-75 \mu \mathrm{g} / \mathrm{kg} / \mathrm{min})$ and same method was followed except that there was no bolus dose of sedative agent. In case the dose of each of the sedative agents was not enough to provide the sedation level (i.e. higher dose was needed), or in case of haemodynamic changes the patients might suffered, a bolus of 25-100 $\mu \mathrm{g}$ of fentanyl was used to achieve the required level of sedation which may be repeated hourly.

\section{Statistical analysis:}

By using SPSS software for windows version 21, data of all patients were entered and analyzed using appropriate coding and analytic statistical tests. Chi square test was used to compare frequencies and percentages. Students $\mathbf{t}$ test was used to compare in between two means while ANOVA test was used to compare more than two means regarding the baseline and parameters and during the monitoring time. Level of significance $(\mathrm{P}$ value $) \leq 0.05$ considered as significant difference.

\section{Results:}

The male to female ratio were $1: 1$ in this study, the mean of the body weight were $73.9 \pm 2$ and $71.8 \pm 3$ for group 1 and 2 respectively. No significant differences between the two groups regarding the age, sex, weight ,days of stay in the ICU, in all comparison P.value $>0.05$. (Table 1) Table 2 show that there is no significant difference between sedation-agitation level, pulse rate, respiratory rate and blood pressure between studied groups ( $\mathrm{P}$ value $>0.05)$.

Table 1: Socio-demographic characteristics of patients groups

\begin{tabular}{|c|c|c|c|c|}
\hline & & \multicolumn{2}{|c|}{ Patients' group } & \multirow[b]{2}{*}{ P. value } \\
\hline \multicolumn{2}{|l|}{ Variable } & $\begin{array}{l}\text { (A) } \\
\text { Propofol }\end{array}$ & $\begin{array}{l}\text { (B) } \\
\text { Dexmed- } \\
\text { etomidine }\end{array}$ & \\
\hline \multirow{3}{*}{$\begin{array}{l}\text { Sex } \\
(\%)\end{array}$} & Male n $(\%)$ & $11(50 \%)$ & $13(59.1 \%)$ & \multirow{3}{*}{$\begin{array}{l}0.20 \\
\mathrm{~ns}\end{array}$} \\
\hline & Female $\mathrm{n}(\%)$ & $11(50 \%)$ & $9(40.9 \%)$ & \\
\hline & Total & $22(100 \%)$ & $22(100 \%)$ & \\
\hline \multirow{2}{*}{$\begin{array}{l}\text { Weight } \\
(\mathrm{kg})\end{array}$} & Mean \pm SE & $73.9 \pm 2$ & $71.8 \pm 3$ & \multirow{2}{*}{$\begin{array}{l}0.61 \\
\text { ns }\end{array}$} \\
\hline & Range & $60-100$ & $50-100$ & \\
\hline \multirow[t]{2}{*}{ Age } & Mean $\pm \mathrm{SE}$ & $36.6 \pm 3$ & $34.6 \pm 2$ & \multirow{2}{*}{$\begin{array}{l}0.63 \\
\mathrm{~ns}\end{array}$} \\
\hline & Range & $17-65$ & $16-55$ & \\
\hline \multirow{2}{*}{$\begin{array}{ll}\text { Days of } \\
\text { stay in } \\
\text { ICU }\end{array}$} & Mean $\pm \mathrm{SE}$ & $5.4 \pm 3$ & $5.3 \pm 1$ & \multirow{2}{*}{$\begin{array}{l}0.97 \\
\text { ns }\end{array}$} \\
\hline & Range & $1-14$ & $1-20$ & \\
\hline
\end{tabular}

ns; not significant.

Table 2: Baseline parameters of patients' groups

\begin{tabular}{|c|c|c|c|c|}
\hline \multicolumn{4}{|c|}{ Patients' group } & \multirow[b]{2}{*}{ P.value } \\
\hline Variable & & Propofol & $\begin{array}{l}\text { Dexmedetomi } \\
\text { dine }\end{array}$ & \\
\hline \multirow{2}{*}{$\begin{array}{l}\text { Sedation- } \\
\text { Agitation } \\
\text { level }\end{array}$} & Mean \pm SE & $6.1 \pm 0.8$ & $5.9 \pm 1$ & \multirow{2}{*}{$\begin{array}{l}0.12 \\
\text { Ns }\end{array}$} \\
\hline & Range & $4-7$ & $4-7$ & \\
\hline \multirow{2}{*}{$\begin{array}{l}\text { Pulse rate } \\
\text { b\min }\end{array}$} & Mean $\pm \mathrm{SE}$ & $111 \pm 11$ & $111 \pm 22$ & \multirow{2}{*}{$\begin{array}{l}0.95 \\
\mathrm{Ns}\end{array}$} \\
\hline & Range & $84-140$ & $65-150$ & \\
\hline \multirow{2}{*}{ SBP } & Mean $\pm \mathrm{SE}$ & $149.5 \pm 15$ & $148.2 \pm 18$ & \multirow{2}{*}{$\begin{array}{l}0.78 \\
\text { Ns }\end{array}$} \\
\hline & Range & $130-190$ & $120-185$ & \\
\hline \multirow[t]{2}{*}{ DBP } & Mean $\pm \mathrm{SE}$ & $93 \pm 11$ & $87 \pm 16.2$ & \multirow{2}{*}{$\begin{array}{l}0.14 \\
\text { Ns }\end{array}$} \\
\hline & Range & $78-130$ & $60-120$ & \\
\hline \multirow[t]{2}{*}{ RR } & Mean \pm SE & $16 \pm 9$ & $21 \pm 6$ & \multirow{2}{*}{$\begin{array}{l}0.11 \\
\text { ns }\end{array}$} \\
\hline & Range & $10-25$ & $10-36$ & \\
\hline
\end{tabular}

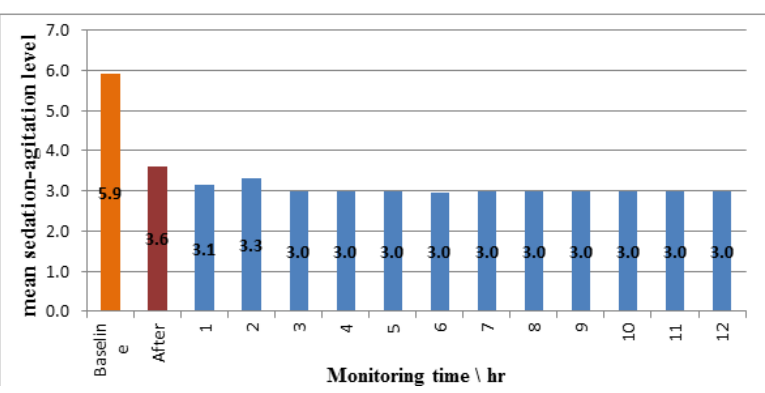

Figure 1. Changes in sedation-agitation level among Dexmedetomidine group.

Regarding to the changes in level of sedation-agitation among group1 it had found that the target was 3 
according to the Riker sedation- agitation scale (figure $1)$.

Figure 2 revealed that the propofol maintenance with adjuvant only give our target in level of sedation (scale $3)$.

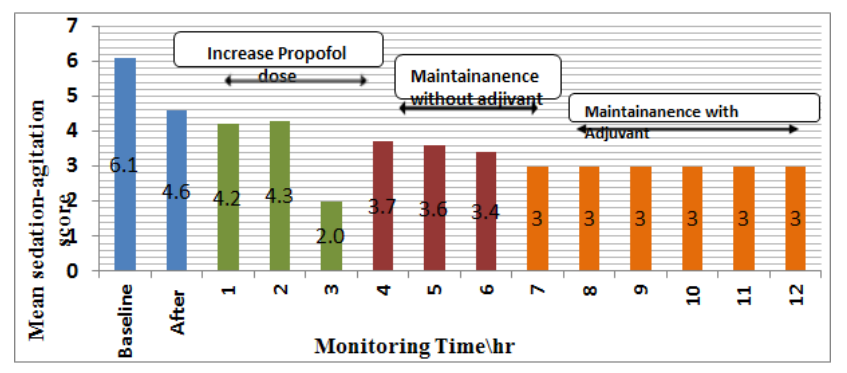

Figure 2.Changes in sedation-agitation level with the change in the dose of Propofol and after administration of adjuvant.

It had been found that mean sedation-agitation level among Propofol group was significantly higher when propofol used alone and significantly lowered with administration of adjuvant, Value $<0.001$. On the other hand dexmedetomidine group had lower sedationagitation level than propofol alone, P.value $<0.001$. (Figure 3)

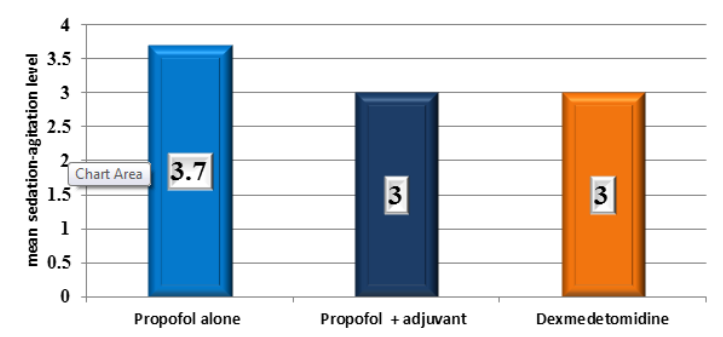

Figure 3: Comparison of mean sedation-agitation score during monitoring time.

\section{Discussions:}

In this study it was found that dexmedetomidine is more effective in sedation with less haemodynamic adverse effect when compared with propofol which can cause more haemodynamic adverse effect when reaching our target level of sedation. On the other hand it's found that dexmedetomidine is as effective as propofol plus adjuvant in the effect of level of sedation and haemodynamic stability. This is in agreement with El baradie S et al (18) study in 2004 who revealed that Dexmedetomidine and propofol are safe sedative drugs for postoperative mechanichally ventilated patients, also in agreement with Stephan M. Jakob et al, which is found that Among ICU patients receiving prolonged mechanical ventilation, dexmedetomidine was not inferior to midazolam and propofol in maintaining light to moderate sedation.
Dexmedetomidine reduced duration of mechanical ventilation compared with midazolam and improved patients' ability to communicate pain compared with midazolam and propofol. (19)Moreover it is similar to that mentioned by many studies (20-23). But it is not agree with El shaer A et al, study in 2012 that found the sedation with dexmedetomidine in doses from 0.7 $1.0 \mu \mathrm{g} / \mathrm{kg} / \mathrm{h}$ can be as effective as, besides being safer than, propofol. Dexmedetomidine in doses less than $0.7 \mu \mathrm{g} / \mathrm{kg} /$ hour may be less effective and probably needs supplementation with other sedative. (2) This may be attributed to the difference in sample size collection.

\section{Conclusions:}

Dexmedetomidine is better than propofol in sedation and haemodynamic stability for patient in ICU, Dexmedetomedine is as effective as propofol plus adjuvant in sedation and haemodynamic stability, Dexmedetomidine can be used as a sole sedative agent in ICU.

Authors' Contributions:

Sabah N.Al. Saad: Choice the idea of the title,put aplan for whole research and made a revision of all over writing of research.

Haitham A. Sahib AlJaafari: Conducted the thesis practically on the patient and writing the thesis.

\section{References:}

1. Yantis MS, Hirsch NP, Smith GB. Anaesthesia and Intensive care A-Z, An encyclopaedia of principles and practice. Fourth edition. Churchill Livingstone Elsevier.2009; 480.

2. El shaer A, Amal HR. Propofol vs low and high doses of dexmedetomidine for sedation of critically ill mechanically ventilated patiants in ICU. Ain shams Journal of Anesthesiology, 2012; 5-1:157,158.

3. Richard R, Richer GL, Fraser LE, Simmons ML. Validating the sedation_agitation scale with bispectral in adult ICU patient after cardiac surgery. Intensive care Med,2001;27:853-858.

4. Diana A, Boris N, Anna N, The role of dexmedetomidine(precedex) in sedation of critically ill patient. Drug Forecast,2005;30(3):158-159..

5.Ralph G, Brown HC, Donald HM, Erin NS. Dexmedetomidine: anovel sedative-analgesic agent. Baylar university medical center proceeding,Dallas, Texas. 2001; 14(1):13-21.

6.Colecchia S, Kobilka BK, Danid KW, Nolan RD, Lapetina EY, Caron MG, et al. Multiple second messenger pathway of alphaadrenergic receptor subtypes expressed in eukaryotic cell. J Bidchem.1990;265:63-69.

7. Jenni $S, R N, M S N$, Use of dexmedetomidine for primary sedation in a general intensive care unit. Critical care nurse, 2010;30(1):29-32. 
8. Coursin DB, Maccioli GA. Dexmedetomidine. Curr oppin crit care,2001;7:221-226.

9. Ronald D. Miller. Miller's Anaesthesia. Sixth edition. Churchill Livingstone Elsevier.2005; 335.

10. Anthony TG, Claire VM. Sedation with dexmedetomidine in intensive care setting. Dovepress Journal:open access emergency medicine,2011;3:7785.

11.Stoelting RK, Miller RD, Basic of anaesthesia.Fifth edition.Churchill Livingstone Elsevier.2007;97-111.

12. Pandharipande PP, Pun BT, Herr DL. Effect of sedation with dexmedetomidine vs lorazepam on acute brian dysfunction in mechanically ventilated patient: the MENDS randomized controlled trial. JAMA, 2007;298(22):2644-2653.

13. Aitkenhead AR, Graham S, Rowbothan DJ.Textbookof anaesthesia.Fifth edition.Churchill Livingstone Elsevier.2007;41-42.

14.Barash PG, Bruce FG, Stoelting RK,Michael KC,Stock MC. Clinical Anaesthesia.Walters Kluwer Lippincott Williams \& Wilkins.2009;445-453.

15. Longnecker OE, David LB, Mark FN, Warren MZ. Anesthesiology.First edition. MC Graw Hill Medical.2008;856.

16. Morgan E, Mikhail MS, Murray MJ. Clinical Anesthesiology.Fouth edition. a LANGE medical book.2006;200.

17. Duke J. Anesthesia secrets. Fourth edition. Mosby Elsevier.2011;92-93.
18. El baradie S, El mahalwy FH, Amira HS. Dexmedetomidine vs propofol for short-term sedation of postoperative mechanically ill patient. Journal of the Egyptian nat. cancer Inst,2004; 16(3):153-158

19. Stephan MJ, Esko R, Grounds RM,Toni S,Chris $G$,Stuart JP,et al. Dexmedetomidine vs midazolam or propofol for sedation during prolong mechanical ventilation in two randomized controlled trials. Caring for the critically ill patient,2012;307(11):1151-1160.

20. Ashraf G, Abdul kadir M,Tapio I, El btarny AM. Dexmedetomidine versus propofol for sedation in patient undergoing vitreoretinal surgery under SubTenon's anesthesia.Saudi Jounal of anaesthesia,2011;5(1):36-41.

21. Azrina MR, Saedah A,Mohad NA,Ziyadi MG,Nik AN.A comparative study of dexmetomidine and propofol for sedation in the cardiothoracic intensive care unit. Int. Med J, 2007;6(2):110-114.

22.Daniel LH,John sum-ping ST,Michael E. ICU sedation after coronary artery bypass graft surgery:Dexmedetomidine-based versus propofolbased sedation regimn.Journal of cardiothoracic and vascular anesthesia, 2003; 17 (5):576-584.

23. Venn RM,Grands RM.a comparision between dexmedetomidine and propofol for sedation in the intensive care unit. Critical care,2001;5(1):195. 